\title{
Erratum to: Behavioral and genetic mechanisms of social evolution: insights from incipiently and facultatively social bees
}

\author{
Wyatt A. Shell, Sandra M. ReHAN \\ Department of Biological Sciences, University of New Hampshire, Durham, NH 03824, USA
}

\section{Erratum to: Apidologie https://oi.org/10.1007//13592-017-0527-1}

The above mentioned article, written by Wyatt A. Shell and Sandra M. Rehan, was originally published electronically on the publisher's internet portal (currently SpringerLink) on 24 July 2017 without open access.

With the society's decision to grant Open Choice the copyright of the article changed to (C)
The Author(s) 2017 and the article is forthwith distributed under the terms of the Creative Commons Attribution 4.0 International License (http://creativecommons.org/licenses/by/4.0/), which permits use, duplication, adaptation, distribution and reproduction in any medium or format, as long as you give appropriate credit to the original author(s) and the source, provide a link to the Creative Commons license and indicate if changes were made.

Corresponding author: S. Rehan, 